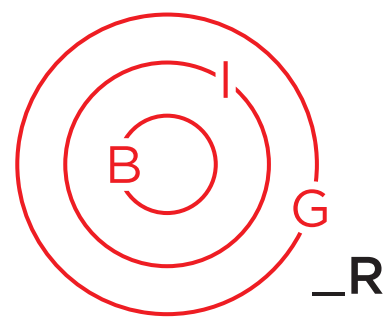

\section{ART \& BORDERS}

In English En français

\title{
On the Passage of Existence: An Interview with Taysir Batniji
}

\author{
Du passage de l'existence: \\ Un entretien avec Taysir Batniji
}

\section{Elisa Ganivet *}

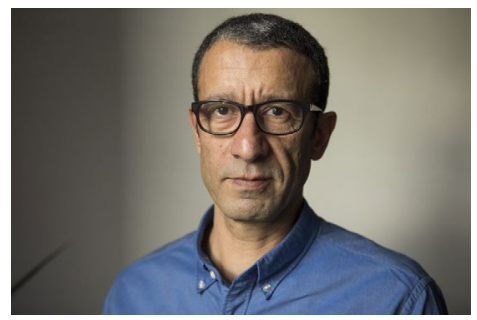

Taysir Batniji (photo credit : Sophie Jaulmes)

www.taysirbatniji.com
In this interview, as part of the special section Art \& Borders, Art Editor Elisa Ganivet talks with the artist Taysir Batniji. The occasion of his exhibition at the Macval (France) allowed reflection on some of his long-term works and on his life path. The strength of 'the idea' prevails over the medium for a sensitive awakening to the state of a world simultaneously foreign and familiar.

Dans cet entretien réalisé pour la section spéciale Art \& Borders, notre rédactrice Elisa Ganivet s'entretient ici avec l'artiste Taysir Batniji. Son exposition au Macval (France) revient sur des pièces phares au long cours ainsi que sur son parcours de vie. Dans son œuvre, la force de l'idée prévaut sur le médium pour un réveil sensible sur l'état d'un monde simultanément étranger et familier.

\section{About the artist}

Born in Gaza in 1966, Taysir Batniji studied art at Al-Najah University in Nablus, Palestine. In 1994, he was awarded a fellowship to study at the School of Fine Arts of Bourges in France. Since then, he has been dividing his time between France and Palestine. Between two countries and two cultures, Batniji has developed a multi-media practice, including drawing, installation, photography, video and performance.

Taysir Batniji's artwork, often tinged with impermanence and fragility, draw its inspiration from his subjective story, but also from current events and history. His methods distance, divert, stretch, conceptualize or simply play with the initial subject, offering, at the end, poetic, sometimes acrid, points of view on reality.

Taysir was awarded the Abraaj Group Art Prize in 2012 and became the recipient of the Immersion residency program, supported by Hermes Foundation, in alliance with Aperture Foundation in 2017. His works can be found in the collections of many prestigious institutions of which the Centre Pompidou and the FNAC in France, the V\&A and The Imperial War Museum in London, the Queensland Art Gallery in Australia and Zayed National Museum in Abu Dhabi.

\section{A propos de l'artiste}

Né à Gaza, Palestine, en 1966. Vit et travaille à Paris. Taysir Batniji a étudié l'art à l'université nationale An-Najah de Naplouse, avant de poursuivre des études en France à l'École nationale supérieure d'art de Bourges entre 1995 et 1997. Depuis, il vit et travaille entre la France et la Palestine où, dans cet entre-deux géographique et culturel, il développe une pratique artistique pluridisciplinaire (dessin, installation, objets / sculpture, performance, etc.) dont l'image, photo et vidéo, est au centre depuis 2000.

L'œuvre de Taysir Batniji, souvent teintée d'impermanence et de fragilité, puise son inspiration dans son histoire subjective, mais aussi dans l'actualité et l'histoire. Par le biais d'une approche distanciée, il détourne, étire, joue avec son sujet initial, de manière à proposer un regard poétique, parfois grinçant, sur la réalité.

Après sa première exposition personnelle à Paris en 2002, ses œuvres ont été largement exposées en Europe et dans le monde, y compris à la Biennale de Venise ; au Jeu de Paume à Paris ; au Martin-Gropius-Bau de Berlin ; à la Kunsthalle de Vienne ; au Witte de With de Rotterdam et au V\&A Museum à Londres. Taysir Batniji est représenté par les galeries Sfeir-Semler (Hambourg/Beyrouth) et Eric Dupont (Paris).

\footnotetext{
* Elisa Ganivet, doctor of philosophy, art historian, author of Border Wall Aesthetics (Columbia University Press 2020), has worked as a cultural manager and curator for international public and private cultural organizations. Web: www.ElisaGanivet.com
} 
Elisa Ganivet: Taysir, our first contact was about ten years ago when I was writing my $\mathrm{PhD}$ in Philosophy on contemporary geopolitical walls and how artists were able to create mobility around the object. From my phenomenological perspective, your Watchtowers series obviously caught my eye. We've been talking a bit over the last few years and finally met at a Parisian café in 2020.

But let's get to the heart of the matter since you have this hot news: your exhibition "Quelques bribes arrachées au vide qui se creuse" (A few snatches torn from the deepening emptiness) at the MAC VAL in Vitry-sur-Seine. This exhibition is a so-called retrospective. Personally, I don't like this expression very much because it gives the impression that you have accomplished everything, whereas no, you still have a lot to do and to make us discover. But what is very beautiful is that we see your own journey as a man, an artist, a Palestinian. It is also the in-between, here neuralgic, that you deliver to us, and that we feel. With the ID Project, 1993-2012, a work that punctuates in a very formal way the administrative meanderings of your history: from your first arrival in Europe, in Italy, until your naturalization in France. However, beyond this aspect, your exhibition is a beautiful capture of this in-between time and we grasp the amplitude of the techniques, supports, mediums with which you work (photography, video, drawing, silkscreen, conceptual installation...). Could you explain to us this notion of in-between, of two geographical spaces, even of two temporalities?

Taysir Batniji: It is true that, for the past ten years, my work has been in an in-between, highlighting the existence of two geographies, two countries, two spaces. Between visibility and invisibility, materiality and immateriality, reality and fiction, the objects and forms I create physically embody this in-between. To My Brother, GHO8O9 and Watchtowers, for example, are dual works: their appearance, invisible for the first and "already seen" for the second, is deceptive and requires a closer look, or closeup, to be perceived accurately. There is a tenuous relationship between what we see from afar and up close, between what we think we see and what really is. While my first works, made at the end of the 1990s, during my first stay in France, evoke a precise place, the one where I come from, where I grew up. They are situated in a historical context, and also reflect my life as a person, an artist, a Palestinian.

Today, I have lived as many years in Palestine as in France. This is why I wanted to update the work Untitled (1998) [Figure 1], the assemblage of objects presenting a suitcase filled with sand. Instead of forming a single pile, in a single section of the suitcase, I decided to present two piles. Because, over the years, the land of the original place, Gaza, Palestine, has been duplicated: I now have another home.

The exhibition at the Mac Val begins with the series of photographs Chez moi, ailleurs (At Home, Elsewhere) (2000, in progress) which insists on this "other home", a present that I give to see, while insisting on its intimate and autobiographical character. It is a selection of images that retrace my life, in bits and pieces, its stages, the different places where I have lived in Europe, transit places (airports, train stations). Until 2006, I was permanently on the move. This work echoes with another home Gaza Diary, which is a photographic series taken during different stays in my original country between 1999 and 2006.

EG: Around the time of the second intifada...

TB: Yes, the second intifada started in 2000, when I decided to
Elisa Ganivet : Taysir, notre premier contact fut il y a une dizaine d'années lorsque j'écrivais ma thèse de philosophie sur les murs géopolitiques contemporains et de la manière dont les artistes créaient une mobilité autour de l'objet. Depuis ma perspective phénoménologique, ta série des Watchtowers m'avait évidemment attiré l'œil. Nous avons un peu échangé ces dernières années et finalement nous nous sommes rencontrés à la terrasse d'un café parisien en 2020.

Mais allons dans le vif du sujet puisque tu as cette actualité brûlante : ton exposition « Quelques bribes arrachées au vide qui se creuse " au MAC VAL de Vitry-sur-Seine. Cette exposition est dite rétrospective. Personnellement, je n'aime pas trop cette expression car cela donne l'impression que tu as tout accompli, alors que non, tu as encore beaucoup à faire et à nous faire découvrir. Ce qu'il y a justement d'impactant c'est que l'on voit ton parcours en tant que toi : une personne, un artiste, un Palestinien. Et c'est également l'entre-deux, ici névralgique, que tu nous fais parvenir, et que nous ressentons dans l'exposition. Avec en filigrane ID Project, 1993-2012, œuvre qui ponctue de façon très formelle les méandres administratifs de ton histoire, de ta première arrivée en Europe, en Italie, jusqu'à ta naturalisation française. Pour autant, au-delà de cet aspect, ton exposition est une belle captation de cet entre-deux et on y saisit l'amplitude des techniques, supports, mediums avec lesquels tu travailles (photographie, vidéo, dessin, sérigraphie, installation conceptuelle...). Pourrais-tu nous expliquer cette notion d'entre-deux, de deux espaces géographiques, voire de deux temporalités?

Taysir Batniji : ॥ est vrai que, depuis une dizaine d’années, mon travail s'inscrit dans un entre-deux, mettant en exergue l'existence de deux géographies, deux pays, deux espaces. Entre visibilité et invisibilité, matérialité et immatérialité, réalité et fiction, les objets et les formes que je crée incarnent d'ailleurs physiquement cet entre-deux. To my Brother, GHO8O9 et Watchtowers sont par exemple des œuvres duelles : leur apparence, invisible pour la première et « déjà vue » pour les secondes, est trompeuse et nécessite un regard approfondi, ou de près, pour être justement perçue. II y a un rapport ténu entre ce que l'on voit de loin et de près, entre ce que l'on croit voir et ce qui est réellement. Tandis que mes premières œuvres, réalisées à la fin des années 1990, lors de mon premier séjour en France, évoquent un lieu précis, celui d'où je viens, où j'ai grandi. Elles sont situées dans un contexte historique, et reflètent également ma vie en tant que personne, artiste, palestinien.

Aujourd'hui, j'ai vécu autant d'années en Palestine qu'en France. C'est la raison pour laquelle j'ai tenu à réactualiser l'œuvre Sans titre (1998) [Figure 1], l'assemblage d'objets présentant une valise remplie de sable. Au lieu de former un seul tas, dans un seul pan de la valise, j'ai

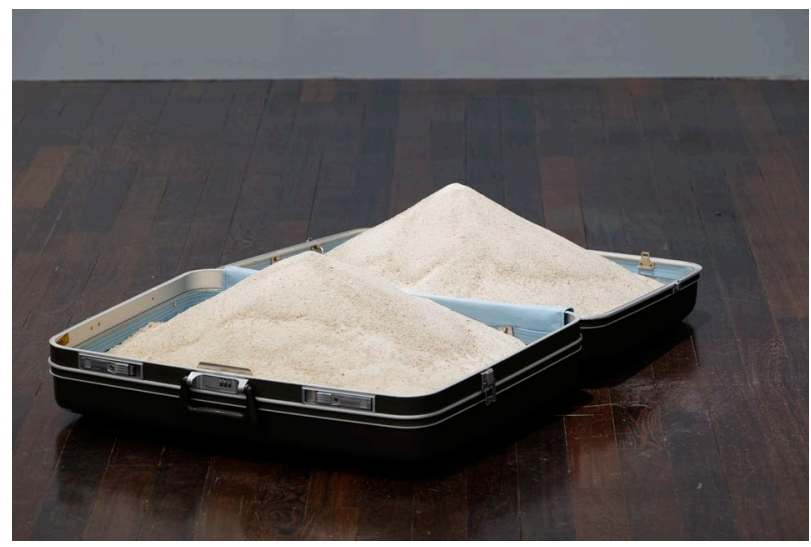

Figure 1. Untitled (1998). Suitcase, sand, variable dimensions. View of the exhibition at MACVAL, 2021. Courtesy of the artist. 
return to Gaza for good. After that, I went back every year until 2006. Then the situation stalled.

EG: Thinking about your travels and moves during this period and while I was visiting the exhibition, I realized that you didn't make large volume artworks, like monumental installations.

TB: Yes. Probably because until 2010, I didn't have a fixed place to work (a studio). For me, it has always been important to be able to store my works. And to be able to move around easily and lightly, without getting bogged down in logistics. I have made many works on paper. Composed of several easily transportable fragments, they unfold in space and can have a monumental scale when exposed. This is also one of the reasons why in traditional terms, I stopped with painting because it requires space, materials, a certain sedentary lifestyle. A different way of life.

EG: Would the installation Inflammable (1997) signal this break?

TB: Yes, there are several works, such as Undefined (1997) [Figure 2] or the untitled key prints on rolled canvas (1997) [Figure 3], that mark this transition from an exclusively pictorial practice to a more multidisciplinary, conceptual practice that evokes the political context in a more concrete, clearer way than before. Even if the starting point remains the personal experience, this one is inscribed in the collective history. The back and forth is permanent.

EG: But precisely, the key is a fundamental element in the Palestinian context. You mention it three times here with the rusty ones on canvas, the glass key ring and also the real estate agency project.

TB: Indeed, for the Palestinians, the key is emblematic. It is a strong symbol because it refers to the history of the Nakba of 1948 , of the dispossession of land, of those Palestinians who kept their keys in the hope of being able to return home one day. The prints of rusty keys on canvas express this collective and historical dimension. While the glass copy of my key ring-the only object I had on me when I found myself unable to return to Gaza in 2006-is more a reminder of a personal trauma.

EG: Related to this symbol, could you explain the real estate agency's project?

TB: These are houses that were bombed during the "Cast Lead" operation carried out at the end of 2008, beginning of 2009 against Gaza. At the time, about 1,500 people died, including 500 children. Many infrastructures and houses were also destroyed. Faced with this destruction, which is reminiscent of the political punishments practiced during the British mandate (the British occupation of Palestine before 1948) and then perpetuated by the Israeli government, my work consisted of paying tribute to these houses and their inhabitants. To make memory. I had the rubble photographed by a friend on the spot who also had the mission of collecting information on these places. I then presented these images in the form of a fictitious real estate agency, in order to create a discrepancy between what the viewer thinks he sees and what he sees.

EG: That's exactly it. While you evoke politics, you manage, through your mode of representation, to bring into play the subtlety of consequences. We don't need to see the raw tragedy. décidé de présenter deux tas. Car, au fil des années, la terre du lieu originel, Gaza, la Palestine, s'est dédoublée : j’ai désormais un autre chez moi.

L'exposition au Mac Val débute d'ailleurs avec la série de photographies Chez moi, ailleurs (2000, en cours) qui insiste sur cet « autre chez moi », un présent que je donne à voir, tout en insistant sur son caractère intime et autobiographique. II s'agit d'une sélection d'images qui retracent ma vie, par bribes, ses étapes, les différents endroits où j'ai vécu en Europe, des lieux de passage (aéroports, gares). Jusqu'en 2006, j'étais en déplacement permanent. Cette œuvre fait un écho avec un autre chez moi : Gaza journal intime, qui est une série photographique prise lors de différents séjours au pays entre 1999 et 2006.

EG : À peu près au moment de la 2ème intifada...

TB : Oui, la 2ème intifada s'est déclenchée en 2000, au moment où j'ai décidé de rentrer définitivement à Gaza. Après, j’y suis retourné chaque année jusqu'en 2006. Ensuite la situation s'est bloquée.

EG : En pensant à tes déplacements durant cette période et alors que je faisais le tour de l'exposition, je me suis fait la réflexion que tu ne réalisais pas d'œuvres en grand volume, de type installations monumentales.

TB : En effet. Sans doute parce que, jusqu'en 2010, je n'ai pas eu de lieu de travail (d'atelier) fixe. Pour moi, il a toujours été important de pouvoir stocker mes œuvres. Et de pouvoir me déplacer facilement et légèrement, sans m'encombrer des questions logistiques. J'ai réalisé beaucoup d'œuvres sur papier. Composées de plusieurs fragments facilement transportables, elles se déploient dans l'espace et peuvent avoir une échelle monumentale sous leur forme exposée. C'est aussi l'une des raisons pour laquelle j'ai rompu avec la peinture, en des termes traditionnels, car celle-ci demande de l'espace, des matériaux, une certaine sédentarité. Un mode de vie différent.

EG : L'installation Inflammable (1997) signalerait-elle cette rupture?

TB : Oui, il y a plusieurs œuvres, comme Undefined (1997) [Figure 2] ou les empreintes de clés sur toiles roulées, sans titre (1997) [Figure 3], qui marquent cette transition entre une pratique exclusivement picturale et une pratique davantage pluridisciplinaire, plus conceptuelle et qui évoque le contexte politique d'une manière plus concrète, plus claire qu'avant. Même si le point de départ reste le vécu personnel, celui-là s'inscrit dans l'histoire collective. Le va-et-vient est permanent.

EG : Mais justement, la clef est un élément fondamental dans le contexte palestinien. Tu la convoques ici à trois reprises avec celles rouillées sur toiles, le trousseau en verre et aussi le projet de l'agence immobilière.

TB : Effectivement, pour les Palestiniens, la clef est emblématique. C'est un symbole fort car se référant à l'histoire de la Nakba de 1948, de la dépossession des terres, de ces Palestiniens qui ont gardé leur clef dans l'espoir de pouvoir retourner un jour chez eux. Les empreintes de clefs rouillées sur toile expriment cette dimension collective et historique. Tandis que la copie en verre de mon trousseau de clefs, le seul objet que j'avais sur moi quand je me suis retrouvé dans l'impossibilité de rentrer à Gaza en 2006, est plus le rappel d'un traumatisme personnel.

EG : Corrélatif à ce symbole, pourrais-tu nous expliquer le projet de l'agence immobilière?

TB : Il s'agit de maisons qui ont été bombardées pendant l'opération " Plomb durci » menée fin 2008, début 2009 contre Gaza. II y a eu à 
Borders in Globalization Review | Volume 3 | Issue 1 | Fall/Winter 2021 Ganivet, "Du passage de l'existence: Un entretien avec Taysir Batniji"

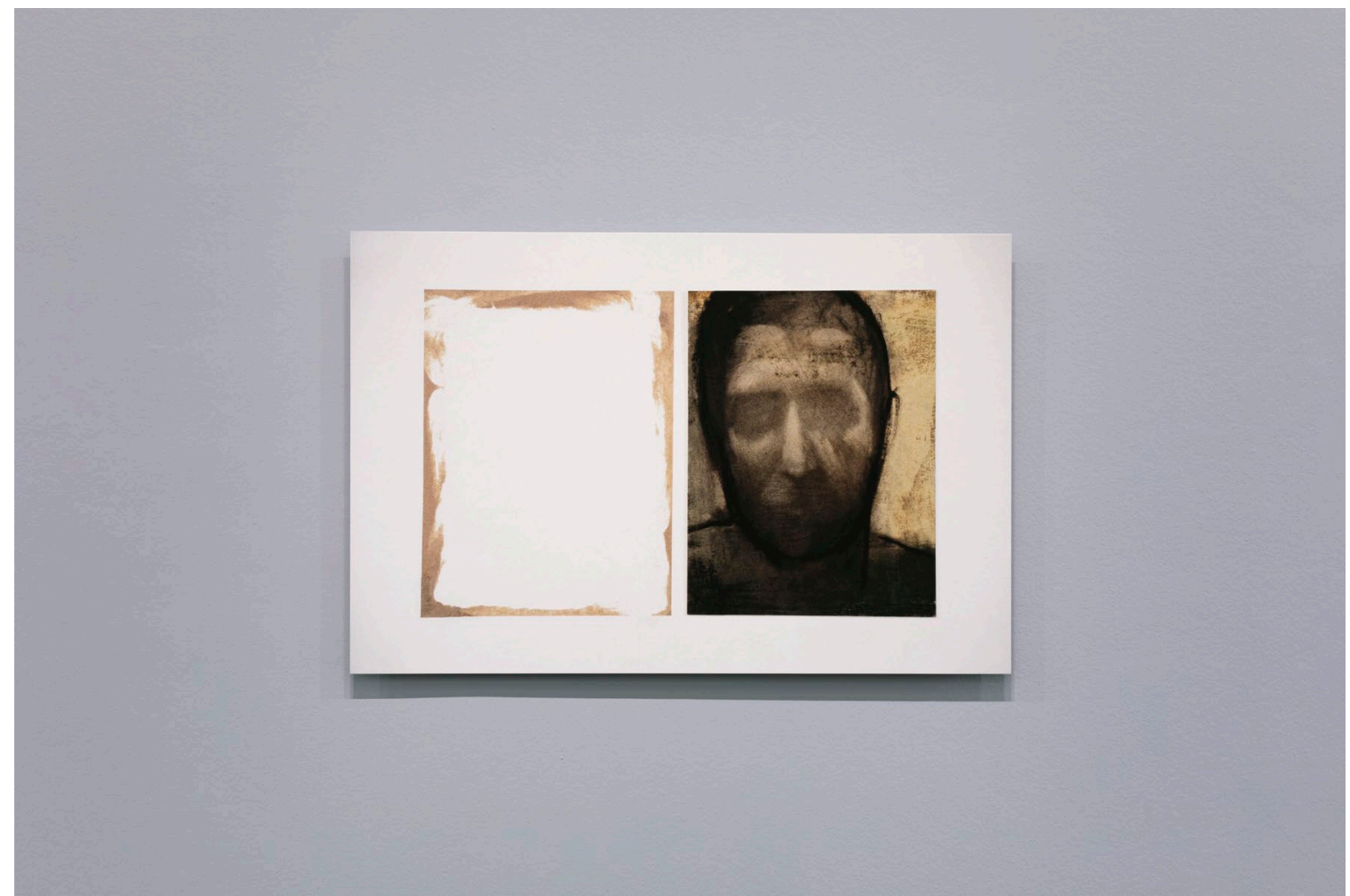

Figure 2. Undefined (1997). Oil on paper, tape, $49 \times 78,5 \mathrm{~cm}$. View of the exhibition at MACVAL, 2021. Courtesy of the artist.

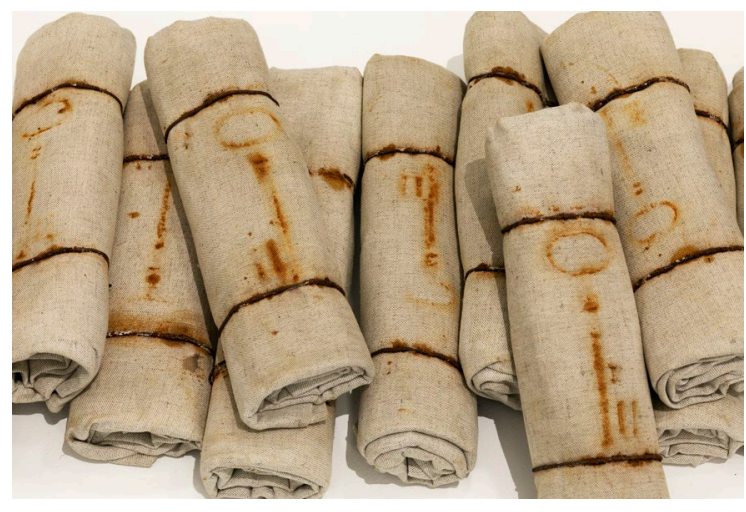

Figure 3. Untitled, detail (1997). Keys imprints on rolled canvas, 20 elements $30 \mathrm{~cm}$ each, View in detail of the exhibition at MACVAL, 2021. Courtesy of the artist.

TB: Yes, it is important to me that my work avoids any victimization, any pathos, any strictly political discourse. To this end, all means are good: fiction, detour... I try to use "filters" to keep a distance.

EG: In the scenography, there is an installation that quite disturbed me. It is the one from your Disruptions series (20152017) [Figure 4] where we see screenshots of Whatsapp conversations with your family. Green covers a large part of the images. We can make out very pixelated streets. The pixel is also one of your favorite motifs. It reminds us of absence, of a materiality that is no longer, or that is becoming. A blur. Moreover, the scenography of the Mac Val transforms this work into a box of vibrations because the wall shakes at the sound of the projection of the video entitled Bruit de fond (2007). l'époque environ 1500 morts dont 500 enfants. De nombreuses infrastructures et habitations ont également été détruites. Face à ces destructions, qui ne sont pas sans rappeler les punitions politiques pratiquées durant le mandat britannique ('occupation anglaise de la Palestine avant 1948) et perpétuées ensuite par le gouvernement israélien, mon travail consistait à rendre hommage à ces maisons et à leurs habitants. Faire mémoire. J'ai fait photographier les décombres par un ami sur place qui avait aussi pour mission de collecter des informations sur ces lieux. J'ai ensuite présenté ces images sous forme d'une agence immobilière fictive, afin de créer un décalage entre ce que le spectateur croit voir et ce qu'il voit.

EG : C'est justement ça. Alors que tu évoques la politique, tu parviens, par ton mode de représentation, à faire jouer la subtilité des conséquences. On n’a pas besoin de voir la tragédie crue.

TB: Oui, il est important pour moi que mon travail évite toute victimisation, tout pathos, tout discours strictement politique. À cette fin, tous les moyens sont bons : la fiction, le détournement... J'essaye d'avoir recours à des « filtres », de garder une distance.

EG : Dans la scénographie, il y a une installation qui m’a assez troublée. C'est celle de ta série Disruptions (2015-2017) [Figure 4] où l'on voit les captures d'écran de conversations Whatsapp avec ta famille. Le vert recouvre une grande partie des images, on y distingue des rues très pixelisées. Le pixel est aussi un de tes motifs de prédilection. II rappelle l'absence, une matérialité qui n'est plus, ou qui est en devenir. Un flou. De plus, la scénographie du Mac Val transforme cette œuvre en caisson de vibrations car la cimaise tremble au son de la projection de la vidéo justement intitulée Bruit de fond (2007). 


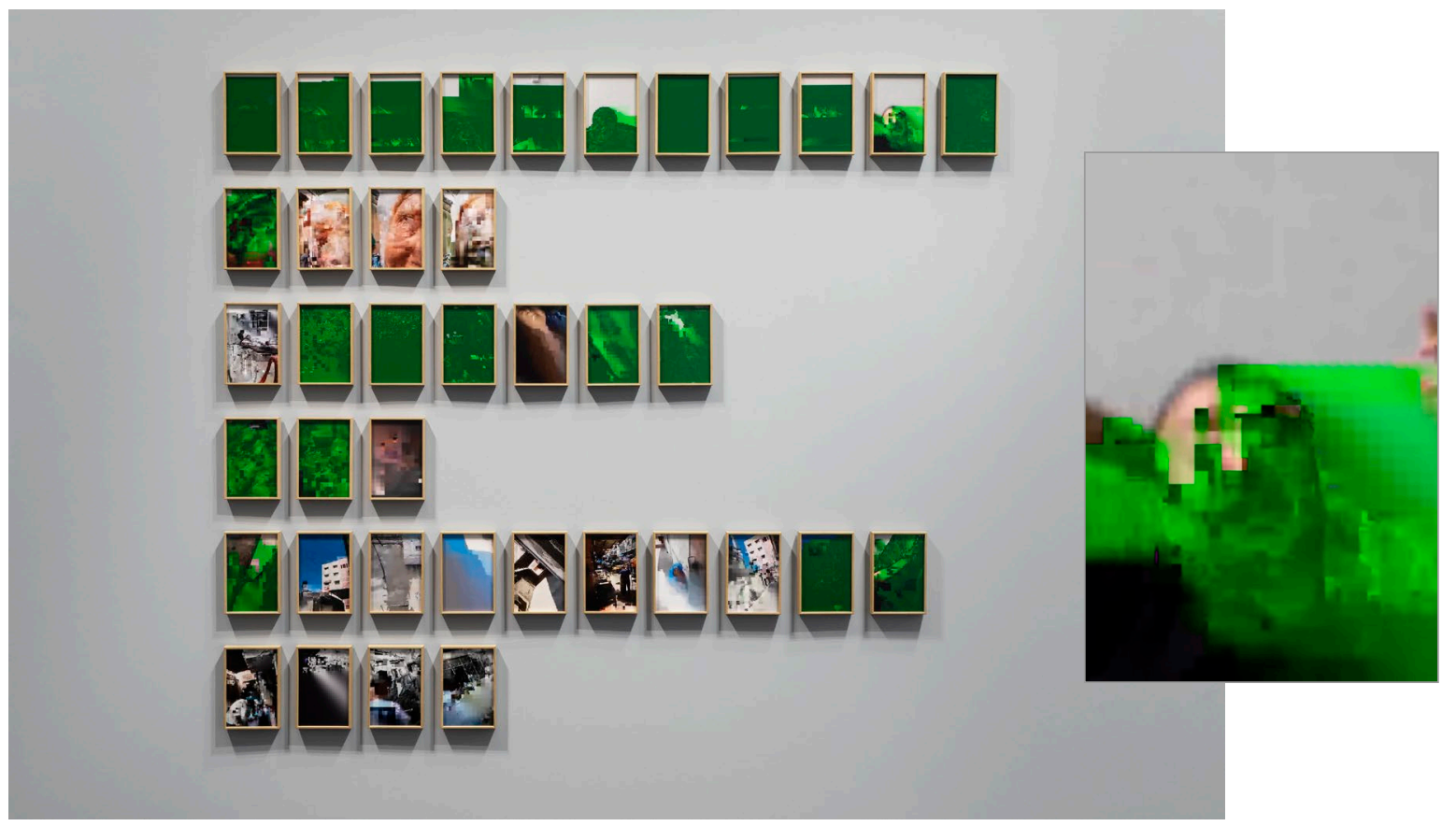

Figure 4. Disruptions (2015-2017). Series of 86 screenshots, inkjet print on Canson Archive satin RC paper, $16 \times 24 \mathrm{~cm}$. Detail and view of the exhibition at MACVAL, 2021. Courtesy of the artist.

TB: When I was communicating with my mother and family in Gaza, the screen would regularly blur, due to the poor connection. The disruption of the network was destructuring the images. Interested by this formal phenomenon, and by the way the faces of my relatives and the streets of my neighborhood were transformed, I wanted to capture these moments. Photography has never been an end in itself for me. I like the way this type of project questions the medium.

EG: So what was the process of the Watchtowers (2008) ? [Figure 5]

TB: These are Israeli military watchtowers in the West Bank photographed in the manner of Bernd and Hilla Becher. The two German photographers documented Europe's post-industrial heritage from the 1950s onwards in a documentary style and according to a precise protocol: frontal images taken with a camera, sharp, without human presence, with subdued, neutral light, etc. In 2004, I went to see their retrospective at the Centre Pompidou in Paris. I was already familiar with their work because my wife, Sophie, was doing her DEA on the documentary style and was interested in the German school of Düsseldorf. When I saw their type of water towers, whose cylindrical shape immediately reminded me of Israeli watchtowers, I was hooked. Four years were necessary for the execution. Unable to go there, I had to find a photographer in the West Bank. In 2008, my friend Dominique Abensour, director of Le Quartier in Quimper, invited me to participate in the exhibition "Our Realities". This is how we were able to get the funds for the production.

EG: How did you locate the watchtowers?

TB: I contacted several people to locate them but they are military buildings. There is no known map. Some photographers were afraid to go there because it could be a dangerous environment.
TB : Lorsque j'étais en communication avec ma mère et ma famille à Gaza, l'écran se brouillait régulièrement, en raison de la mauvaise connexion. La perturbation du réseau déstructurait les images. Interpellé par ce phénomène formel, et par la façon dont se transformaient les visages de mes proches et les rues de mon quartier, j'ai tenu à capter ces instants. La photographie n'a jamais été pour moi une fin en soi, j'aime la manière dont ce type de projet interroge le médium.

EG : Quel fut donc le procédé de la série des Watchtowers (2008)? [Figure 5]

TB: ॥ s'agit des miradors militaires israéliens en Cisjordanie photographiés à la façon de Bernd et Hilla Becher. Les deux photographes allemands ont documenté à partir des années 1950 le patrimoine post-industriel européen, dans un style documentaire et selon protocole précis : des images frontales prises à la chambre, nettes, sans présence humaine, avec une lumière tamisée, neutre, etc. En 2004, je suis allé voir leur rétrospective au Centre Pompidou de Paris. Je connaissais déjà leur travail car ma femme, Sophie, faisait son DEA sur le style documentaire et s'intéressait à l'école allemande de Düsseldorf. En voyant leur typologie de châteaux d'eau, dont la forme cylindrique m’a immédiatement rappelé celle des miradors israéliens, j’ai eu le déclic. Quatre années furent nécessaires pour la mise en exécution. Ne pouvant me rendre sur place, j'ai dû trouver un photographe en Cisjordanie. En 2008, mon amie Dominique Abensour, directrice du Quartier à Quimper, m'a invité à participer à l'exposition « Nos réalités ». C'est ainsi que nous avons pu avoir les fonds pour la production.

EG : Comment avez-vous fait pour localiser les miradors?

TB : J'ai contacté plusieurs personnes pour les localiser mais ce sont des bâtiments militaires. II n'y a pas de carte connue. Certains 


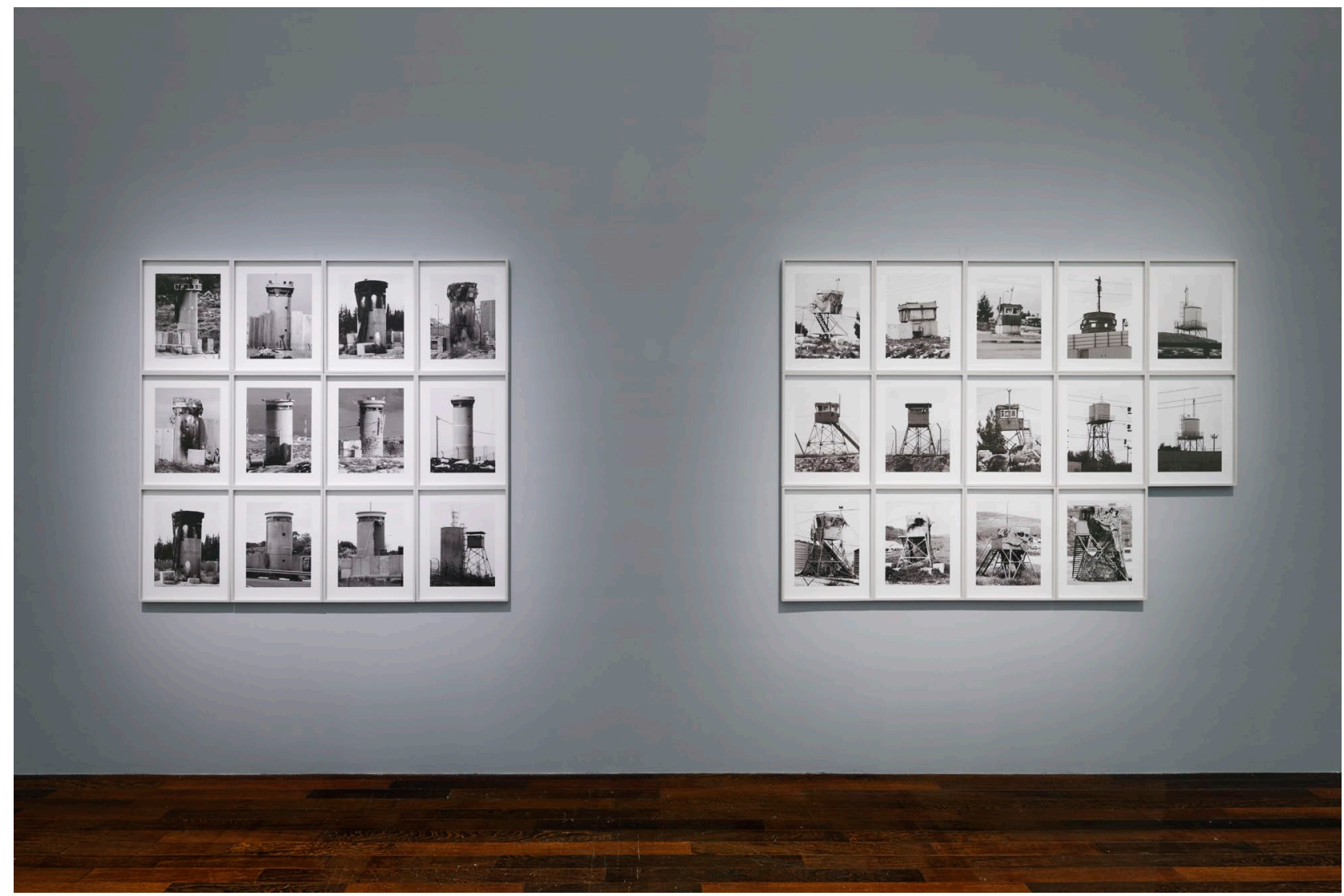

Figure 5. Watchtowers (2008). Series of 26 photographs, black and white digital prints, $40 \times 50 \mathrm{~cm}$. View of the exhibition at MACVAL, 2021. Courtesy of the artist, photo: Dieter Kik.

Other people put me in touch with Israeli photographers who were willing to do this work, but I wanted it to be seen from the Palestinian side. Even if my first idea was to do as the Bechers did, to work with a camera, to take the time... We quickly realized that installing this type of equipment in a guarded military zone, moreover without accreditation, was impossible. The delegated photographer had to work with a normal digital camera equipped with a telephoto lens to take pictures from a distance. Sometimes, he took the picture while passing in a bus or in a car, or even hidden behind a tree... As a result, contrary to the perfect images of the Bechers, who follow the protocol to the letter, the photographs of Watchtowers are sometimes blurred, pixelated, in backlight, etc. Because it was impossible to take the time to pose. What seemed to be flaws eventually became an advantage, because the goal was not to imitate the Bechers identically. It was just enough to create the illusion from a distance. At first glance, one thinks that this is one of their series, but a second time, one realizes that it is not. The precariousness of the photos, their defects, indirectly evoke the situation. Without making a speech on what is a watchtower, on the complexity of the displacement, one feels all this tension which surrounds it, the difficulty, the danger to approach it.

EG: I draw a parallel with one of Rula Halawani's series, The Wall at Night (2004), who herself confessed to being afraid of the concrete wall and approached it at night, as if to tame it.

TB: Indeed, but it must have been complicated for her...

EG: I didn't know and I really like the video Me 2 (2003). It looks like a photographes avaient peur d'y aller car le contexte pouvait être dangereux. D'autres personnes m'ont mis en contact avec des photographes israéliens qui étaient disposés à réaliser ce travail, mais je voulais que ce soit vu du côté palestinien. Même si ma première idée était de faire comme les Becher, de travailler à la chambre, de prendre le temps... On s'est vite rendu compte qu'installer ce type de matériel dans une zone militaire surveillée, de surcroít sans accréditation, était impossible. Le photographe délégué a dû travailler avec un appareil numérique lambda muni d'un téléobjectif pour photographier de loin. Parfois, il prenait la photo en passant dans un bus ou dans une voiture, ou encore caché derrière un arbre... Du coup, contrairement aux images parfaites des Becher, qui suivent à la lettre le protocole, les photographies de Watchtowers sont parfois floues, pixelisées, en contre-jour, etc. Car il était impossible de prendre le temps de la pose. Ce qui semblait être des défauts est finalement devenu un avantage, car le but n'était pas d'imiter les Becher à l'identique. II était juste suffisant de créer l'illusion de loin. Au premier regard, on pense qu'il s'agit d'une de leurs séries, mais dans un second temps, on se rend compte que non. La précarité des photos, leurs défauts, évoquent indirectement la situation. Sans faire de discours sur ce qu'est un mirador, sur la complexité du déplacement, on ressent toute cette tension qui l'entoure, la difficulté, le danger de s'en approcher.

EG : Je fais le parallèle avec l'une des séries de Rula Halawani, The Wall at Night (2004), qui confessait elle-même avoir peur du mur en béton et qui s'en approchait de nuit, comme pour l'apprivoiser. 
burst of pure resistance, a scream. We see you turning with two different angles on this song performed by Gloria Gaynor.

TB: I was in Marseille at the time, between the end of 2002 and the end of 2003, when the Americans were preparing the war in Iraq. In spite of all the demonstrations against it, it seemed that everything was heading towards this war. The situation described by the media in France, full of clichés towards the Iraqis, was unclear, ambiguous, even perverse.

EG: A Manichean image?

TB: Yes, while the majority of international opinion was against the war, the positioning of the media did not reflect the reality on the ground, the feelings of the Iraqis, the way they lived the situation. I could no longer watch the television news (France 2, in particular). I decided to install my camera, like a filter, and to film them. With the vague idea that one day I might do something with these rushes. In the end, Me 2 is the assembly of two sequences: on the first one, I turn like a dervish, carrying the camera at arm's length, filming what I see. On the second, the camera is posed (fixed) and films me while shooting. As for the Gloria Gaynor song, I got it from a carnival that I filmed in Marseille. The interweaving of the two sequences produces a double look: that of a man who turns and sees himself turning. This performative video is a spontaneous gesture, a kind of cry against war, a will to win or, at least, to survive.

EG: To face up to it. Precisely in situations where the population is vulnerable and in distress, you also manage to capture, to extract an essence from the situation to make it more universal. We start from our own vulnerability, as individuals, and the added excess by the catastrophic political and geopolitical situations. Your personal experience with Gaza Diary or To my Brother, for example, expresses this.

TB: It is true that To My Brother (2012) [Figure 6] is a special work because it is about my missing brother who was killed by the Israeli army in 1987 at the beginning of the first Intifada. I think
TB : En effet, mais cela a dû être compliqué pour elle...

EG : Je ne connaissais pas et j'aime beaucoup la vidéo Me 2, (2003). On dirait un élan de pure résistance, un cri. On te voit tourner avec deux angles différents sur cette chanson interprétée par Gloria Gaynor.

TB : J'étais à Marseille à l'époque, entre fin 2002 et fin 2003, au moment où les Américains préparaient la guerre en Irak. Malgré toutes les manifestations contre, il semblait que tout allait vers cette guerre. La situation décrite par les médias en France, pleine de clichés envers les Irakiens, n'était pas claire, ambigüe, voire perverse.

EG : Une image manichéenne?

TB : Oui, alors que l'opinion internationale s'est majoritairement prononcée contre la guerre, le positionnement des médias ne rendait pas compte de la réalité sur le terrain, du ressenti des Irakiens, de la manière dont ils vivaient la situation. Je ne pouvais plus regarder les journaux télévisés (celui de France 2, notamment). J'ai décidé d'installer ma caméra, comme un filtre, et de les filmer. Avec la vague idée qu'un jour peut-être je ferai quelque chose de ces rushes. Finalement, Me 2 est l'assemblage de deux séquences : sur la première, je tourne comme un derviche en portant à bout de bras la caméra qui filme ce que je vois. Sur la deuxième, la caméra est posée (fixe) et me filme en train de tourner. Quant à la chanson de Gloria Gaynor, je l'ai récupérée lors d'un carnaval que j'ai filmé à Marseille. L'imbrication des deux séquences produit un double regard : celui d'un homme qui tourne et se voit tourner. Cette vidéo performative est un geste spontané, une sorte de cri contre la guerre, une volonté de vaincre ou, tout du moins, de survivre.

EG : Faire front. Justement dans des situations où la population est vulnérable et en détresse, tu parviens aussi à capter, à extraire une essence de la situation pour nous la rendre plus universelle. On part de notre propre vulnérabilité, en

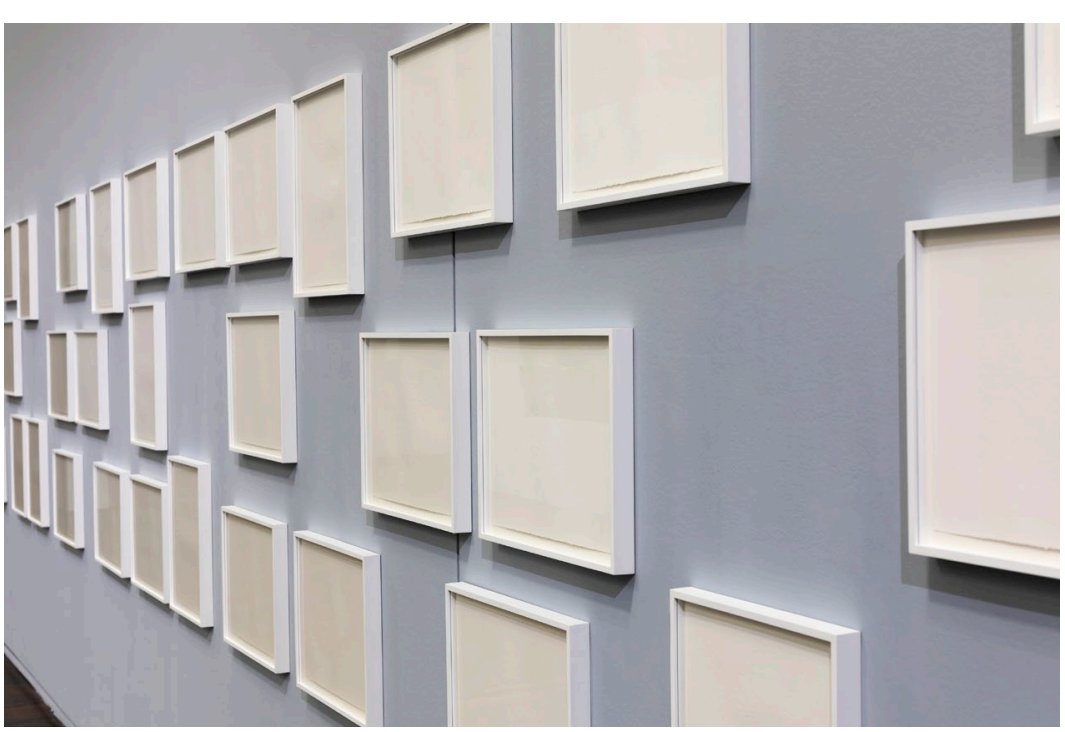

Figure 6. To my brother (2012). Series of 60 hand carvings from photographs on paper, $30.5 \times 40.5 \mathrm{~cm}$. Detail (right) and view of the exhibition at MACVAL, 2021. Courtesy of the artist.

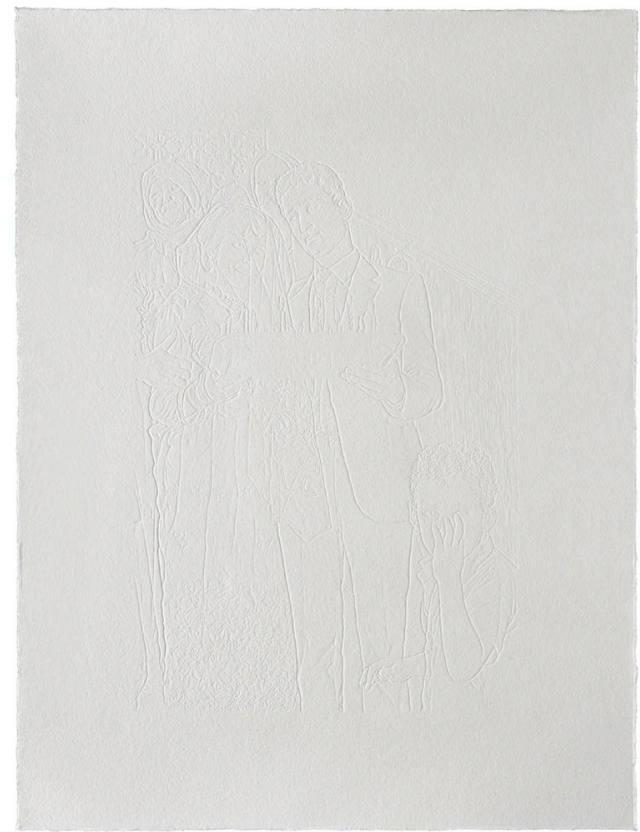


this story affected me a lot and had an impact on my work, especially on the works related to disappearance, absence. Basically, beyond the political prism and current events, beyond the war which can only be a one-off, I am above all interested in the human dimension. What happens on the fringe of the bombings? How do people live? Because nothing lasts forever. In fact, I dedicated one of my works to this observation: Nothing is permanent (2014). Wars, occupation, what a people lives at a time $T$ are only passages in History. The situations all change one day. And what remains is the human, the daily life. What people do, what they tell.

EG: How did you react to the clashes last spring 2021?

TB: As usual when something happens. I feel helpless, because I am geographically far away. I wonder what I can do. These are times when I am active on Facebook. I try to share, to inform, to comment on events, to help people understand what is going on, to read between the lines. Because obviously I feel concerned. But these are times of anguish, of concern for my family on the spot. I try to call often, to be in contact with my relatives, I make sure they are well, I tell them that I am thinking about them, etc. What is incredible, and painful, is that although these kinds of events make the headlines, as soon as the episode is over, the situation is forgotten. It is forgotten that people are still living with the trauma of what has just happened. Since 2006, there have been four successive wars. A large number of houses have been bombed without ever being rebuilt. The trauma can be seen in the children. There are many cases of suicides. No one talks about it because there is no future, no political perspective. Fifteen years ago, there was still a horizon, a hope that this situation would be resolved. Now there is nothing. The Israeli government literally has "carte blanche". The situation is left to rot, under the pretext that Gaza is controlled by Hamas. But I think that everyone has their share of responsibility. Whatever the position towards Hamas, we forget that the Gazan population did not choose and that, since 2007, they have suffered poverty, malnutrition and insecurity.

EG: What do you think when people mention "diaspora artist"?

TB: I don't really like labels. And l've always had a reluctance to use the word "exile". It's a very heavy word. It's a word with no way out. For my part, I always keep the hope of being able to go home, to live here and there, I refuse to consider myself as "exiled".

EG: But here this is also your home, you have a family, you have built...

TB: Yes of course, but I am cut off from my home there. My children were only able to go to Gaza once. They were very small. And it's hard for me to pass on the language to them.

EG: But they understand you when you speak to them in Arabic.

TB: A little. They have one Arabic class a week because I want them to learn, not to lose contact with the language. I try to speak to them every day in Arabic but it's not easy every day.

EG: Speaking of transmission, you went to see your family who lives in California. You had done this project with drawings tant qu'individu, et du surplus ajouté par les situations politiques et géopolitiques catastrophiques. Ton expérience personnelle avec par exemple Gaza journal intime ou To my Brother l'exprime.

TB : Il est vrai que To my Brother (2012) [Figure 6] est une œuvre particulière puisqu'il s'agit de mon frère disparu, tué par l'armée israélienne, en 1987, au début de la première Intifada. Je pense que cette histoire m'a beaucoup affectée et qu'elle a eu un impact sur mon travail, notamment sur les œuvres en lien avec la disparition, l'absence. Au fond, au-delà du prisme politique et de l'actualité, au-delà de la guerre qui ne peut être que ponctuelle, je m'intéresse surtout à la dimension humaine. Que se passe-t-il en marge des bombardements ? Comment vivent les gens ? Car rien ne dure jamais. D'ailleurs, j'ai consacré l'une de mes œuvres à ce constat : Rien n'est permanent (2014). Les guerres, l'occupation, ce que vit un peuple à un instant « $\mathrm{t}$ » ne sont que des passages dans l'Histoire. Les situations changent toutes un jour. Et ce qui reste c'est l'humain, la vie quotidienne. Ce que font les personnes, ce qu'elles racontent.

EG : Comment as-tu réagi face aux affrontements du printemps de 2021 ?

TB : Comme d'habitude lorsqu'il arrive quelque chose. Je me sens impuissant, car je suis géographiquement loin. Je me demande ce que je pourrais faire. Ce sont des périodes durant lesquelles je suis actif sur Facebook. J'essaye de partager, d'informer, de commenter des événements, d'aider les gens à comprendre ce qu'il se passe, à lire entre les lignes. Car évidemment je me sens concerné. Mais ce sont des périodes d'angoisse, d'inquiétude pour ma famille sur place. J'essaye de téléphoner souvent, d'être en contact avec mes proches, je m'assure qu'ils vont bien, je leur dis que je pense à eux, etc. Ce qui est incroyable, et douloureux, c'est que, bien que ce genre d'événements fasse la une des journaux, dès que l'épisode est fini, la situation retombe dans l'oubli. On oublie que les gens continuent à vivre le traumatisme de ce qu'il vient de se passer. Depuis 2006, il y a eu quatre guerres successives. Un grand nombre de maisons ont été bombardées sans jamais être reconstruites. Le traumatisme se lit à travers les enfants. II y a beaucoup de cas de suicides. Personne n'en parle car il n'y ni avenir, ni perspective politique. Il y a une quinzaine d'années, il y avait encore un horizon, un espoir de voir cette situation se résoudre. Maintenant, il n'y a plus rien. Le gouvernement israélien a littéralement carte blanche. On laisse la situation pourrir, sous prétexte que Gaza est contrôlée par le Hamas. Mais je pense que chacun a sa part de responsabilité. Quelle que soit la position vis-à-vis du Hamas, on oublie que la population gazaouie n'a pas choisi et que, depuis 2007, elle subit pauvreté, malnutrition et insécurité.

EG : Que penses-tu lorsque l'on mentionne « artiste de la diaspora »?

TB : Je n'aime pas trop les étiquettes. Et j’ai toujours eu une réticence à l'égard du mot « exil ». C'est un mot très lourd. Sans issue. Pour ma part, je garde toujours un espoir de pouvoir aller chez moi, de vivre ici et là-bas, je refuse de me considérer comme « exilé ».

EG : Mais ici c'est aussi chez toi, tu as une famille, tu as construit...

TB : Oui bien sûr, mais je suis coupé de chez moi là-bas. Mes enfants n'ont pu aller à Gaza qu'une seule fois. Ils étaient très petits. Et j'ai du mal à leur transmettre la langue.

EG : Mais ils te comprennent quand tu leur parles en arabe.

TB : Un peu. Ils ont un cours d'arabe par semaine car je tiens à ce qu'ils apprennent, qu'ils ne perdent pas le contact avec la langue. J'essaye de leur parler au quotidien en arabe mais ce n'est pas facile tous les jours.

EG : En parlant transmission, tu es parti voir ta famille qui vit en Californie. 

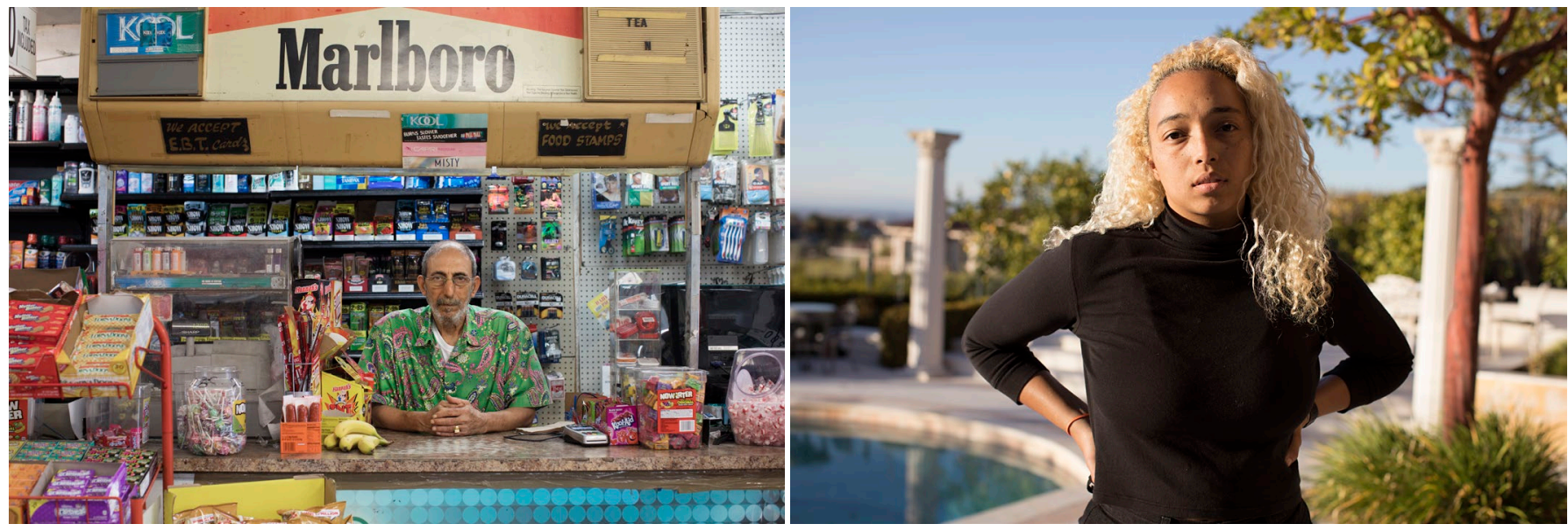

Figure 7. Home Away From Home / Adam (2017). Series of 26 pigment inkjet prints on Canson photo satin premium paper, $55 \times 37 \mathrm{~cm}$. Courtesy of the artist.

and photographs: Home Away from Home / Adam (2017) [Figure 7].

TB: Yes, it was a funny situation because my cousins turned out to be both familiar and foreign. I knew them very young and very little. They moved to the United States in the late 1960s to the mid-1980s. So, once I was at their home, I felt a certain frustration because I was in the midst of my family, yet I felt like a stranger. Like I was in Gaza without being there. This ultimately exacerbated my frustration at not being able to be with my family in Gaza. It also awakened memories, situations that were buried inside me.

EG: In your exhibition at the Mac Val, we understand in particular the coherence and evolution of your thinking. But more than continuity, I think there is a lot of endurance in the body of your work.

TB: That's what was important in this exhibition and, for me, it's a great opportunity to be able to gather my work, to have visibility, to step back on what l've done so far. It's like an assessment, a time for reflection, before continuing. It's a gestation in progress.

EG: To see what will come next, step by step... To remain patient.

TB: Yes, in the middle of this very particular period, because of Covid among other things. At the moment I am preparing an exhibition at the Mathaf in Doha. So I still have to wait before going back to the heart of my creative process.
Tu avais réalisé ce projet avec dessins et photographies: Home Away from Home / Adam (2017) [Figure 7].

TB : Oui, c'était une drôle de situation car mes cousins se sont avérés être à la fois familiers et étrangers. Je les ai connus très jeune et très peu. Ils se sont installés aux États-Unis entre la fin des années 1960 et le milieu des années 1980. Alors, une fois chez eux, j'ai senti une certaine frustration car j'étais au sein de ma famille, tout en me sentant étranger. Comme si j'étais à Gaza sans y être. Cela a finalement exacerbé ma frustration de ne pouvoir être avec ma famille de Gaza. Cela a également réveillé des souvenirs, des situations qui étaient enfouies en moi.

EG : Dans ton exposition au Mac Val, on comprend en particulier toute la cohérence et l'évolution de ta pensée. Mais plus qu'une continuité, je pense qu'il y a beaucoup d'endurance dans le corpus de ton œuvre.

TB : C'est ce qui était important dans cette exposition et, pour moi, c'est une belle opportunité de pouvoir rassembler mes œuvres, d'avoir une visibilité, du recul sur ce que j'ai réalisé jusque-là. Comme un bilan, un temps de réflexion, avant de poursuivre. C'est une gestation en cours.

EG : De voir ce qui va se profiler ensuite, step by step... De rester patient.

TB : Oui au milieu de cette période très particulière, à cause du Covid entre autres. En ce moment, je prépare une exposition au Mathaf de Doha. Alors je dois encore attendre avant de retourner au cœur de mon processus de création. 